\begin{tabular}{|c|c|c|}
\hline Preatident: & G. B. Pnestron & $\begin{array}{l}\text { Departurent of Mathematics, } \\
\text { Moases University } \\
\text { Clayton, Vic. } 3168\end{array}$ \\
\hline Secretary: & W. R. BLoOM & $\begin{array}{l}\text { School of Mathematical and } \\
\text { Phycical Sciences, } \\
\text { Musdoch University, } \\
\text { Murdoch, WA } 6153\end{array}$ \\
\hline $\begin{array}{l}\text { Treasurer and } \\
\text { Desiness Manager: }\end{array}$ & B. D. Jowns & $\begin{array}{l}\text { Department of Mathematies, } \\
\text { Univertity of Queensland, } \\
\text { St Lucia, Q1d } 4067\end{array}$ \\
\hline Associate Treasurer: & D. G. TACON & $\begin{array}{l}\text { Sethool of Mathematics, } \\
\text { University of New South Wales, } \\
\text { Kensington, NSW } 2033\end{array}$ \\
\hline $\begin{array}{l}\text { Membership ndecriptions } \\
\text { for 1903: }\end{array}$ & $\begin{array}{l}\text { Institutions: } \\
\text { Ortinary membars: } \\
\text { Reciprocal and junior members: } \\
\text { Sustaining members: }\end{array}$ & $\begin{array}{l}\text { A } 333 \text { (this includes all publications) } \\
\text { A } 538 \\
\text { A } 519 \\
\text { A } 576\end{array}$ \\
\hline
\end{tabular}

Reciprocity agreements: Such agreements have been made with a number of other mathematical societies. Under the agreements members of the other societies who are not normally resident in Australia may join the Australian Mathematical Society at half the current rates.

Membership and correspondence: Applications for membership and other correspondence, except as noted below, should be sent to the Secretary. Member's subscriptions, notiee of change of address or titke or position, and correspondence related to accounts should be seat to the Associate Treasurer. Correspondence about the distribution of the Society's GAZETTE, JOURNAL and DULIETIN, and orders for back numbers, should be sent to the Business Manager.

Members receive the Ganette free and are entitled to purchase other publications at the following rates (1983): Journal (Series A) for A\$17 per year, Journal (Series B) for A\$12 per year, and Bulletin for As17 per year.

\title{
OTHE PULUCATIONS OF THE SOCICTY
}

THE JOURNAL SERIES A (PURE MATHEMATICS AND STATTSTICS)

Editor: Dr T. E. HaLI,

Department of Mathematics.

Monash University,

Clayton, Vic. 3168

Six parts will be published in 1983, and the cost for 1983 is A $\$ 120$. Manuscripts should be sent to the Editor or an Associate. Editor listed in Series A.

THE BULLETIN of the Australian Mathematical Society aims at quick publication of original research in all branches of mathematics. Normally two volumes of three parts are published annually. The eost in 1983 is A\$114 per year. Esch peper for publication shovid inelude an abstract and a 1980 Mathematics Subject Classification. Three copies of the typescript should be sent to the Editor:

D. S. A. Mouns,

Departmeat of Machematics.

La Trobe University,

Bundoora, Vic. 3083

The Australian Mathematical Society GAZETTE started publication in 1974 and carries news items. mathematical articles of general interest, and articles on tertiary mathematics teaching. The cost in 1983 is AS19 per year. Manuicripts for publication should be seat to the Editor:

Dr J. D. GanY,

School of Mathematics,

University of New South Wales,

Kensingloa, NSW 2033

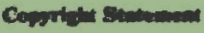

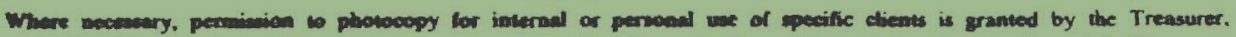

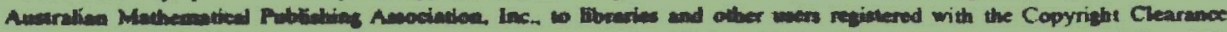

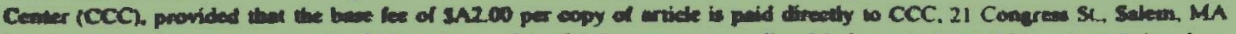

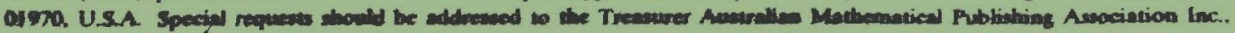

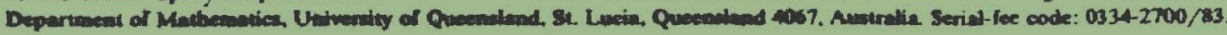




\section{PRDPARATION OF MANUSCRIPTS}

Authors of articles submitted for publication in the Journal are asked to ensure that their manuscripts are in a form suitable for sending to the printer. The Editor reserves the right to return poorly presented material to authors for revision.

1. Submission. The author should submit two copies to the Editor or an appropriate Associate Editor and keep a complete copy of the article. At least one submitted copy should be free of editorial marks.

2. Abstract. An abstract not exceeding 250 words should accompany each copy of the manuscript.

3. Style. The manuscript should conform to the following rules. In case of any doubt, authors are advised to refer to previous papers in the Journal.

Main headings should be numbered, centred and shown thus:

\section{Preliminary results}

The titles Lama, Theorem, Proof, Corollary, Remark, Derinition etc. should be indented and numbered consecutively with Arabic numerals, c.g.

Leava I. The content of the lemma, theorem eic should follow, as here.

Manuscripts should be typed, on high quality A4 or quarto bond paper, one side only with at least double spacing, and with a margin of at least $4 \mathrm{~cm}$ all around. If the title is long, supply also a shortened form of the title not exceeding 40 characters, including spaces. If acknowledgements of support and assistance are made, these should be given at the end of the article. Footnotes should be avoided. The address should be shown under the author's name.

4. Equations. Equations should be typed wherever possible, and punctuated to conform to their place in the syntax of the sentence. Equation numbers should be shown on the right in round brackets.

If possible avoid complicated notations such as subscripts of subscripts, and use $\exp (. .$.$) if the$ exponent is non-trivial. The use of a solidus / often makes fractions and quotients easier to set.

5. References. The reference list should be in ALPHABETICAL ORDER by name of first author, preceded by a reference number in square brackets. These references should be cited in the text by giving the appropriate number in square brackets. The following layout for books, journal articles, technical reports, theses, articles in books, and conference proceedings respectively must be followed:

[1] M. Abramowitz and I. A. Stegun (eds.), Handbook of mathematical functions (Dower. New York, 1970).

[2] S. N. Biswas and T. S. Santhanam, "Coherent states of para-Bose oscillators", J. Austral. Math. Soc. Ser. $B 22$ (1980), 210-217.

[3] F. H. Busse, "On the mean field problem of thermal convection", Max-Plenck Inst. Phys. Astrophys. Rep MPI-PAE/Astro 31 (1970), 1-31.

[4] E. M. Casling, "Slender planing surfaces", Ph. D. Thesis, University of Adelaide, 1978.

[5] R. H. Day, "Adaptive processes and economic theory", in Adaptive economic models (eds. R. H. Day and T. Groves), (Academic Press, New York, 1975), 1-38.

[6] J. W. Miles, "Resonant response of harbors (the harbor paradox revisited)", Proc. 8th Symp. Naval Hydro. (1970), 95-115.

6. Tables. Each should be typed on a separate sheet with a centred heading TABLE 1. (or 2,3, etc.). followed by a caption. The location should be shown in the texh, e.g.

TABLE I NEAR HERE

7. Figures. Each figure should have a caption beginning: Figure 1. (or 2,3, etc.). A list of these captions should be provided on a separate page at the end of the manuscript. Location of figures in the text should be shown, e.g.

\section{FIOURE 1 NEAR HERE}

Figures should be drawn in black ink with clean lines; do not use a ball point pen. The paper should be of a non-absorbent quality so that the ink does not spread and produce furzy lines. If the figures are intended for reduction they should be drawn with lines heavy enough that they do not become flimsy at the desired reduction. The lettering should be of professional quality and in proportion for the expected size reduction. That made with dry transfer lettering, lettering guide or seriber is most appropriate. If none of these possibilities is available, write in the lettering with pen or pencil, not obliterating any lines of the drawing; the lettering will then be typeset.

8. Units. The SI system of units should be used. 